\title{
The Implementation of the Principle of Equality and Non-discrimination in Family Relationships in Albania
}

\author{
Ph. D. Candidate Erjona Molla
}

University of Tirana; erjona_m@yahoo.com

Doi:10.5901/ajis.2016.v5n2p31

\section{Abstract}

\begin{abstract}
The healthy family and marriage relationships are a contribution for the elimination of gender stereotypes. Everything starts in the family and then is transmitted in the society. The major discrimination against women takes place in their homes, this is much influenced by our patriarchal culture. All provisions of the Family Code that address the conjugal rights and obligations care about not making the difference between the husband and the wife. It is very important that when we talk about gender equality we shall well-use the term "equality". Together, both men and women, need more freedom in order to develop and express their personal features, their individuality, their diversity, their femininity and masculinity respecting others and each other in any environment, including family relationships. This means that gender equality should govern family life, couple's relationship, relations with children and all components of parental responsibility, relations in the work environment, in various aspects of social and public activity, even the respect for themselves.
\end{abstract}

Keywords: Family Code, gender equality, non-discrimination, family relationships.

\section{Introduction}

The perception of the principle of equality in close relation with discrimination due to gender, made possible a better understanding of guarantees for the transformation of gender equality, in a real equality. Women were deprived of many rights, and generally not only of the rights of a political nature, but also economic and social ones.

It is difficult to define gender equality, including all the elements that characterize its core. However, for a better understanding helped the contemporary doctrine and especially the jurisprudence of courts and international institutions. Thus, it is defined not only in terms of formal gender equality but also the essential and material one. The Law "On gender equality in society" the gender equality is defined as equal participation of women and men in all fields of life, equal position between them, equal opportunities and chances for the enjoyment of rights and to fulfill the obligations in society, equally benefiting from the achievements of its development.

So, the law identifies equality, not only as a guarantee of equal chances and opportunities, but also as a guarantee for participation and equal enjoyment of benefits in society.

"A person is not born a woman, but becomes a woman" is a famous saying of Simone de Beauvoir. Starting from the toys that we purchase we understand that I am preparing by the parents for a life that takes place outdoors, while the girls for a life that takes place primarily within the family. But is this right? These social differences, these imposed roles does not do anything else but suppress the normal and the natural development of people, especially when it comes to the delicate ages: children and teens. "Do not play with dolls, this is a game for girls" - adults say to a little boy. While they say to the girl: "You are like a naughty boy, climbing on trees and playing football?" Throughout their lives, men and women are under pressure to behave as required by gender differences with social nature. Thus, men are encouraged to be more initiative, decision-making, leading, while girls submissive, taciturn, and in service to others. It has nothing to do with the nature or the innate potentials of boys and girls. Society imposes men and women different roles in society and determines which properties are desirable for girls and women and which for boys and men.

\section{The Principle of Equality between Spouses in the Marriages}

The healthy family and marriage relationships are a contribution for the elimination of gender stereotypes. Everything starts in the family and then is transmitted in the society. Article 16 of CEDAW addresses the problem of discrimination against women in the private sphere, including the discrimination in the field of family law. A major discrimination against women takes place in their homes by their husbands, family members or communities. This field of discrimination usually 
rely on old cultural and religious practices which, as such, are among the hardest to change.

Articles 50-65 of Family Code address "the rights and obligations derived from marriage". The article 50 of Family Code expressly provides that "After the marriage, the husband and the wife enjoy the same rights and assume the same obligations." All the provisions of the Family Code which address the conjugal rights and obligations care about not making the difference between the husband and the wife. Each of them has the right and obligation to express the free and full will regarding the main issues of marital life, including the issues related to the children, helping in the realization of the cohabitation and the family, but also to undertake judicial initiatives, to repel the actions and decisions of the other spouse that become a risk or violate the implementation of marital rights and obligations. In theoretical terms, from the analysis of these provisions we understand:

- the reciprocal character of marital rights and obligations, reciprocity required in loyalty, moral help, material help and collaboration in the interest of the family and the cohabitation;

- acceptance of equality as a social concept and as a principle of family law found in the rights and obligations for the spouses in relation to each other, in relation to the children, in relation to the marriage and the family.

- The non-discrimination and placing above all the interests of the children; marriage; family.

For some of the rights and obligations, the spouses preserve a degree of autonomy, while some others leave no such opportunity because the provision is imperative. This right of self-determination of the spouses depends on the importance of one defined right or obligation. The Family Code provides and promotes the principle of the voluntary adherence of rights and obligations guaranteeing the protection in case of violation or misuse of the discretion. As such are listed: urgent measures, measures against violence, the granting of the authorization by the court, sequestration of goods, eviction order, etc. The spouses have equal rights to file a complaint to the court for the violation of marital family obligations.

it is noted that the contribution for marriage is self-regulated by the spouses in the agreement on the regime. In the absence of adjustments in the contract of regime then the Family Code provides for that each of the spouses contributes according to the opportunities and conditions. This important provision promotes unity. In marriage, the material aspects despite their importance, are secondary. The love, sympathy, respect, support and understanding etc. should be the same, but not assets and contributions. It depends from case to case. Although the provision is important, the risk of the abuse with it exists, by the spouse who claims that has no conditions and opportunities and does not fulfill the family obligations. Despite the efforts for equality and fair division of works and responsibilities in services and family care, women yet have a double burden - work outside their house (if they are employed) and the care for the children and a variety of works and care within the house. It is very important that the standards of gender equality must take into account this role of women or men if appropriate, in order that the legislation, social consciousness and family emancipation leave more space for their protection providing a division of obligations and works for the growth of children, health care, education and training, etc. On the other hand, men seek to expand their obligations, that in fact, are also their rights, for example, they want more space to play better the role of the parent, father and contributor in the family. We shall not forget that often the pressures exerted on men remain hidden and put them in a discriminatory position. When we talk about gender equality we should not handle issues which have to do with gender discrimination of women. This may lead us in the beginning of the first efforts. In order for the society to move forward, to have prosperity and development, is required a combination, harmony and collaboration of men and women. Together men and women are part of the problem but also part of its solution with the aim of materialization of the gender equality which start in the family and then transposed in the society.

\section{Protective Measures to Guarantee the Realization of the Principle of Equality and Non-discrimination in the Family Relationships}

As a rule, the obligations derived from the marriage should be implemented voluntarily and with understanding between the spouses. In cases of violation and abuse, the Family Code (articles 58-64) has provided for the interventions of the public authority (the court) when one of the spouses does not want to fulfill the obligations voluntarily. The Court starts the proceeding upon the request of the other spouse. Such cases may lead to:

- The authorization by the court for one of the spouses to perform the legal actions in the interest of the family, in cases when the other spouse opposes this action or is not able to perform it (article 58).

- The representation of the spouse, in cases when he is not able to express his will, by the other spouse (article 59).

- The fulfillment by one of the spouses of the urgent needs of the family, as the maintenance of the family, 
education of children, interests of the family and the solution of other situations with urgent character (article $60)$.

- The cases of "penalties" when one of the spouses does not visibly fulfill his obligations and jeopardizes the interests of the family.

Article 62 on measures against violence protects men and women equally as spouses against the violent actions of the other spouse These provisions are limited and protects only spouses but with the emergence of the law "For protective measures against violence in the family relationships (2006 amended) is given the concept of the family members that are protected and is made a complete regulation. In this way is important that these laws refer to each other in order to have a clear legal context in relation to the violence in the family and the protective measures. In this case "the Law for measures against violence in the family relationships" is a solution for the uncertainty and difficulty in the implementation of article 62 of Family Code. In addition there are also the provisions of the Criminal Code, where the last amendments provide also the criminal offense of domestic violence.

\subsection{Which are some urgent measures provided for by law?}

- Sequestration of goods of the evicted spouse to the appropriate extent (56/2).

- The authorization of the court to perform a legal action for which is needed also the consent of the other spouse (58).

- The authorization of the court to represent the other spouse in legal actions related to the matrimonial property regimes.

- Eviction order for the violent spouse (62).

\subsection{What is the duration for these measures?}

- These measures, having an urgent character, may not be imposed for a period longer than 3 years.

\subsection{Something about the surname of spouses and children}

The issue of the surname seems to have found extensive treatments also in the international jurisprudence turning this case by case in a sensitive issue but also discriminatory. The surname is one of the main components of the civil state of citizens". The issue of the surname should be seen in two aspects: the surname of spouses with the conclusion and dissolution of marriage and the surname of children. According to the Albanian legislation, the spouses, after the conclusion of marriage, have the right to choose as a mutual surname, one of their surnames or each of them shall keep their respective surnames. No one may be imposed the surname. In the case of marriage dissolution, the spouse who has changed his surname, after the dissolution of marriage, takes the surname that had before the marriage. This happens automatically. Upon a request of the spouse to the court and a verification by it that is in his/her interest or in the interest of the children, to be permitted to have the surname taken after the conclusion of marriage.

Regarding the surname of the children, if the parents have a mutual surname, this is also the surname of the children. The parents decide by agreement in relation to the surname of children. The Family Code provides that in case of disagreement the children shall bear the surname of their father. In this way, is noted an incorrect attitude of the Family Code against the adherence of the standards of gender equality. It would be correct that in such case the children bear the surname of the two parents listed in alphabetical order and then, when the children reach the adulthood, for purposes of documentation and ease, they would have the right to choose one of the surnames decided in this way.

The surname of spouses or children, constituting a sensitive issue has become the subject of proceedings at the European Court of Human Rights. So, in the case Burghartz against Switzerland, ECHR, 22 February 1994, found that for the issue of surname's choice, women had the opportunity to add their surname to the surname of their husband only because the possibility defined in relation to the surname in this law, was the surname of the husband. The spouses could take the surname of women only in the case of a legitimate interest. The Court found men and women as victims, as this case belonged to both spouses. Burghartz opposed the lack of the possibility that the spouses add their surname to the surname of the family (the surname of the wife) when this option was permitted for women. The state argued that the difference was justified due to the defined provision that the parties must take the surname of the husband as their surname. In the other case, Unal Tekeli against Turkey, ECHR cites a series of legal international instruments of United Nations and the Council of Europe and referred to the fact that Turkey was the only member state that had discriminatory 
provisions in relation to the surname. Unnal Tekeli opposed the prohibition of women to use their maiden surnames when this possibility was permitted for men. The state tried to justify its position based on the need to reflect the unity of the family through the surname of men. In both cases, the court referred to the nature of the Convention as an instrument and declared that Article 14 of the European Convention of Human Rights prohibits the discriminatory provisions in relation to the surname.

The issue of the surname was presented as worrying also at CEDAW Committee (The Committee that acts in the framework of the Convention for the Elimination of all forms of Discrimination against Women). So, the procedures related to the issue of the surname which while making evident the sensitivity of subjects in relation to this personal right enable to analyze in a comparative overview the standards contained in the Albanian legislation.

\section{Conclusions}

- The Law "On gender equality in society" regulates the fundamental issues of gender equality in the political life, protection and equal treatment of women and men, for equal opportunities and chances for the exercise of rights and their participation and assistance in the development of all areas of social life.

- The legal arrangements have positively contributed to the achievement of gender equality and the regulation of marital relationships in this respect.

- It is important that the legal framework is fully applicable to our society.

- The family environment directly affects the formation of gender roles for boys and girls.

- Throughout their lives, men and women are under pressure to behave as required by gender differences with social nature.

- The achievement of de facto gender equality except de jure gender equality is a serious concern of our society.

- Women have still a double charge because they have to work inside the house, take care of family members and work outside the house in cases when they are employed.

- CEDAW has had a significant positive impact in our society for the protection of women against various forms of discrimination.

- Together, men and women are part of the problem but also part of its solution with the aim of materialization of gender equality standards which begin in the family and then are transmitted to society.

- The various laws which are in force and their implementation, promotion of equal opportunities, prospects and constraints in relation to gender equality and discrimination are largely borrowed from those of developed western countries.

\section{References}

The Constitution of the Republic of Albania (1998)

Family Code Law no. 9062/8.5.2003

Law no. 9970/28.7.2008 "On gender equality in society"

Law no. 10129/5.11.2009 "On civil status"

Law no. 10221/4.2.2010 "On the protection against discrimination"

\section{Webliography}

http://www.ikub.al/LIGJE_CATEGORY/112170005/Article_Per-disa-ndryshime-ne-Kodin-e-Familjes-se-Republikes-se-Shqiperise-.aspx https://sq.wikibooks.org/wiki/Kodi___Familjes http://www.osce.org/sq/albania/32828?download=true

http://www.sociale.gov.al/files/userfiles/SKBGJ-RDHBGJDHF2011-2015.pdf

http://80.78.70.231/pls/kuv/f?p=201:Ligj:130/2013:25.04.2013 


\title{
Rural Road Infrastructural Challenges: An Impediment to Health Care Service Delivery in Kabba-Bunu Local Government Area of Kogi State, Nigeria
}

\author{
Gbadamosi, K. T . PhD, FCILT \\ Olorunfemi, S. 0 \\ Department of Transport Management Technology, Federal University of Technology \\ P.M.B 704, Akure, Ondo State, Nigeria
}

\author{
Doi:10.5901/ajis.2016.v5n2p35
}

\begin{abstract}
In spite of the diverse rural development policy programmes designed address improvement in the condition of rural dwellers in Nigeria, the health needs of many of the rural environment are still being hindered due to inadequacy of rural road transport infrastructures. This situation has put the health of the rural dwellers in jeopardy and invariably makes them vulnerable to curable health challenges with known solutions in tertiary health centres in urban areas. Transport infrastructural challenges have made it relatively difficult encourage the required medical and health personnel to be attracted to working the rural areas of the country. The above situation is responsible for the untold hardship rural dwellers are facing in accessing appropriate healthcare. This study examined the rural road transport infrastructural challenges as an impediment to health care service delivery in Akutupa-Kiri village of Kabba Bunu Local Government area of Kogi State. The study was carried out through structured questionnaire and reconnaissance survey to ascertain the situation. The data were presented using descriptive analytical method. Findings revealed that road transport infrastructures is required to support qualitative health care delivery as poor road network and high transport cost has been found to be responsible for problematic access to medical treatment. The poor transport infrastructures and epileptic nature of transport infrastructure situation compounded health workers ability in the handling of health emergencies in the rural areas. The above situation has negatively impacted on health care delivery in the area. The study recommended construction of motorable roads with adequate infrastructures and creation of Agency or Board that could monitor rural infrastructures particularly transport infrastructures to facilitate easy movement and accentuate healthcare delivery in the area on a positive note.
\end{abstract}

Keywords: Transport, Infrastructure, Healthcare, Movement, Rural.

\section{Introduction}

Rural areas are otherwise known as the country side and their main economic activities in most part of Africa in which Nigeria constituted a part is mainly agriculture. Nigeria is predominantly a rural society considering the fact that greater proportion of her populace resides in the rural areas (Ele, 2006; Nwuke, 2004; Ugwuanyi and Chukwuemeka, 2013). Nigeria is ranked among the first ten (10) oil producing nations in the world. Despite Nigeria's activities in the area of oil production a larger proportion of her population still remains heavily dependent on agriculture as main source of employment.

Rural country sides' of Nigeria have not witnessed any meaningful development despite their significant roles in the process of economic emancipation of the country before the advent of oil. Several opinions have been expressed to catalog the neglect of rural areas by the power that be in the provision of infrastructures since independence. Ugwuanyi and Chukwuemeka, (2013); Obguu,(2010); Okakuri, (2006); Olorunfemi and Basorun, (2013) all have demonstrated the impact of lack of basic infrastructural facilities most especially how the neglect of transport sector has resulted in poor quality of life with its attendant implication on rural dwellers access to healthcare facilities judging from inadequacy of accessibility to healthcare facilities and personnel. Transport infrastructural challenge in rural areas of developing countries has been identified as a key restraint in the realization of effective child and maternal healthcare goals.

Anita et al, (2014) has identified the key hindrances for assessing healthcare service to include among others; long distances to facilities, inadequate and unaffordable transport cost, poor quality of care, and poor governance and accountability mechanisms. Anita et al, (2014) has reiterated the need for smooth and prompt vehicles to address health emergence at lower level or higher level of healthcare delivery as the case may be. The absence of road transport infrastructures in most of the rural areas have been a great challenge limiting rural dwellers accessibility to healthcare 
facility, thereby reducing their performance and efficiency (Anita et al, 2014). Akutupa-Kiri is one of the major villages in Kabba-Bunu Local Government area of Kogi State, Nigeria with population of Four thousand seven hundred and twenty five $(4,725)$ people (NPC, 1991).

The area is endowed with abundant fertile soil, good for agricultural produce but has been hindered to perform at its fullest capacity due to the poor road condition. This study provided an insight to the transport infrastructural challenges posing as threat to the provision and access to healthcare facilities in Akutupa-kiri village. The overall objectives of this study is to examine the available style and strategies of transport infrastructural provision and the impact of same on accessing social economic services / infrastructure with particular reference to healthcare facilities.

\section{Research Methodology}

The methodology of study involved the use of primary and secondary. 1991 Population Census figures were used in the determination of the sample size for the study. The Nigerian National Population Commission projected a bench mark of 4725 people with a growth rate of $2.8 \%$ which amounted to 8,918 people in 2014. Taro Yamane's formula was used to establish the sample size, as shown below:

$$
\begin{aligned}
& \mathrm{n}=\frac{N}{1+N(e)^{2}}=\mathrm{n}=\frac{8918}{1+8918(0.08)^{2}} \\
& =156
\end{aligned}
$$

Where: $n=$ Sample size

$\mathrm{N}=$ Population

$\mathrm{e}=$ Level of precision in $\%=$ level of precision or sampling error at 0.08 .

The 156 respondents were selected as the sample population. The household head of the population were sampled. Systematic sample method was used to pick respondent at every $5^{\text {th }}$ interval within the sample population in the study area.

A questionnaire was also designed to elicit vital information from the health officers at the cottage hospital Akutupa-kiri. Univariate analytical technique was used to establish the perception of residents of the area on the impact of transport infrastructures on socio-economic development of the area as well as its impact on access to health care facility.

\section{Conceptual Framework and Literature Review}

To create a context for a clearer appreciation of the discussion and analysis, the following concepts of the study are clarified below:

Transport and Development: The cyclical relation between transport and development has been emphasized by different school of thought and there is no gain saying that transport improves the utility of space and product by ensuring that goods are transported to the location where it can be best be utilized.

Meanwhile, Development is a household concept in both the developed and developing countries (Ugwuanyi, and Chukwuemeka, 2013). Development has been hypothesized by different school of thought. Some see it as a period of change while some see it as a time of new innovation, advancement and improvement. Adewole (2013) see development as period of transformation, advancement to a better and desired state of positive transformation. In relation to the above, Okoli and Onah (2002) state that development has to do with progression, movement and advancement towards something better. They stressed further that the movement include both material and non-material aspects of life. In any case, the prevailing conception of development connotes enhancement in the well-being of people (Okoye, 2000; Ugwuanyi, and Chukwuemeka, 2013). In the actual sense, development entails modernization or westernization (Ele, 2006; Ugwuanyi, and Chukwuemeka, 2013)). For instance, technological innovation has provided unique transformation to the development of transport to overcome the challenge of distance as well as comfort requires to achieving interaction over the year.

However, through transport development, movement across the globe has been made through production of sophisticated vehicle, aircraft and ships. Hence, this type of opportunity is highly beneficial to the urban people while the rural people are totally neglected.

\subsection{Literature Review}

Transport infrastructure is of necessity for the development of any location particularly in accessing healthcare facilities 
and other human activities in space. Several researchers have discussed the challenges facing the rural dwellers particularly in the area of spatial mobility, which is very crucial to the economic and social survival of any community or society. For instance, Annabel (2000) based on his research in Zambia, opines that transport infrastructures appears to be a significant concern for villagers. Fatoke (2013) noted that in most developing countries, locations of healthcare facilities more often than not favours urban area to the neglect of rural area. This implies that urban population enjoying better health services than the rural population who are the majority. This inequity in the distribution of health care facilities is responsible for many health problems prevalent in the rural areas. There is no doubt that rural people who constituted more than $60 \%$ of the nation population lack development in term of physical facilities (Adereti, 2005).

Rural accessibility is also an important factor that should be considered in improving rural dwellers' health and condition. This assertion has been stressed out by authors like Shoup, (2006), Basorun (2004), Okoko (2006), that the ability and propensity of an area or a particular land use types to attract traffic will decline as the land use types or the area becomes more distant or remote from people or materials it is meant to attract. This shows that distance is a trip deterring factor in the sense that longer distance discourages traffic (i.e. the longer the distance the less to traffic experience) (Okoko, 2006). In line with the above, accessibility is seen as important consideration in setting or location of health care centre for the rural dwellers. Upon this, Alabi (2011, Aregbeyan , 1992) in their studies the overall importance of access to healthcare facilities as yardstick for measuring quality of life but this in most cases are constrained by challenges of physical accessibility of a household members to health care facilities in most rural milieu in Nigeria. In fact, it has been stated that the greater the distance between two (2) points, the lower the probability of these points being functionally related (Alabi, 2011). A large number of studies have shown a regular waning in accessibility to health facilities with increasing distance in road transport journeys to hospitals (Alabi, 2011; Barjis, 2013; Anita, 2014). Equally, some studies that were undertaken in different parts of Nigeria have similarly shown variation in maximum distance which people travel to utilize health facilities, for instance, Adejuyigbe (1977) and Adeyemo (2005) noted that there is a limit to the distance, which people are ready to travel in order to enjoy some health services. They further maintained that attendance at each medical centre is a function of both type of services available in the medical centre and the distance from other medical centre providing similar service (Alabi, 2011).

Despite the strategies and policies of the government at all levels of governance in improving the life of rural dwellers with programmes and policies among the programs include; Directorate of Roads and Rural Infrastructure (DFRRI) to enhance infrastructure development in the rural areas, River Basin Development Authorities (RBDAs), Rural Electrification Scheme, Better Life for Rural Women Programme, National Directorate of Employment (NDE), Millennium Development Project targeted at Rural Infrastructure, Rural Banking Programme, and provision of Micro credit Finance to provide financial support for rural economy and provide financial services to the rural poor. (Ajadi, 2010; lyagba and Anyanwu, 2012; Ugwuanyi and Chukwuemeka, 2013). It is unfortunate that all this efforts has not yielded any improvement in the quality of life of rural dwellers. The ineffectiveness of government policy programmes may not be unconnected with corrupt practices among government officials as reported by Ezeah, (2005); Ugwuanyi and Chukwuemeka (2013), Adeewole (2013) .

\section{Study Area}

Akutupa Kiri is a town in Kabba/Bunu Local Government of Kogi State in central region of Nigeria and is situated at $8^{\circ} 27^{\prime} \mathrm{N} 6^{\circ} 24^{\prime} \mathrm{E}$ with population of 4,725 . The language of Akutupa- kiri isYoruba while their local language is called Kiri and their traditional occupations is farming (Sibiri et al, 2014).

The road that links Akutupa-Kiri is a Federal road that transverse through lluke-Bunu and terminated at Egan in Lokoja Local Government Area of Kogi State. Having realized the socio-economic activities of the people along the route, the federal Government approved the construction of the road from Ayetoro- Gbede in ljumu Local Government to Eggan in Lokoja Local Government Area of Kogi State respectively. The construction stated in 2001 and about 50km of the road was constructed and this terminated at Suku in Kabba-Bunu Local Government area of the state, while other part of the road was abandoned up to this moment. This situation has worsened the mobility of people residing along the route (Akutupa-Kiri inclusive) and has great effects on their trading activities and healthcare services. Akutupa-Kiri has a cottage Hospital but the condition of the road has affected the operational efficiency of the centre due to poor road, lack of mobile network and other social amenities that could have aid the development in the area. The map below shows the kabba-Bunu Local Government in its National Setting and Akutupa-Kiri the study location 


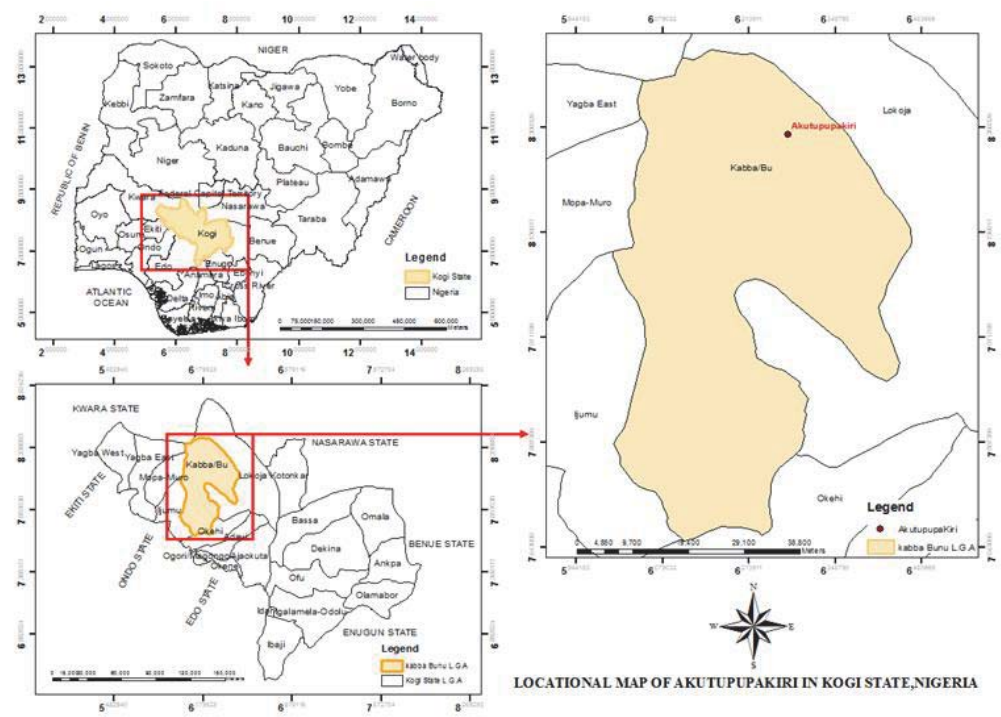

Source: Kogi State Town Planning Board, Lokoja and modify by Authors 2014

\section{Data Presentation and Discussion}

\subsection{Socio-Economic Characteristic of the Respondents}

The analysis in Table 1 shows the socio-economic characteristics of the respondents in Akutupa-kiri, the study location. It was revealed in the analysis that females were $62.8 \%$ while the males were $37.2 \%$ in the study area. This is a confirmation of the 1991 population census statistics which revealed that females are more than their males' counterpart in the area. The marital status of the respondents' shows that majority (64.10\%) of the people in the area are married. It was reflected that $35.2 \%$ of the respondents fall between ages $51-60$ years. The educational background of the respondents reveals that majority (61.0\%) had primary school education and $23.1 \%$ are without formal. This type of level of education is so synonymous to the rural area simply because many of them give up at this stage and settle for other means of livelihood particular farming or trading. In corroboration with the above Olorunfemi (2013) opines that this is the limit of free education opportunity in Nigeria and where education is still affordable by the average poor. In most cases, those who meet requirements for higher education give up at this stage for businesses because of the cost involved.

The occupational status reveals that majority $(60.3 \%)$ are farmers while quite number of them also involved in trading activities for their survival. This is attributed to fact that rural area is mostly characterized as an agrarian region as majority of her populace remains heavily dependent on agriculture as main source of employment. Analysis into the annual income shows that majority (60.3\%) of the respondents earned between N200,001- N300,000 annually. This implies that majority of the respondents still live below average living standard as indicated by the United Nation and this may affects the people's standard of living, health condition and their ability to demand for housing and requirement for other services Olarenwaju, (1996); Agbola, and Agunbiade (2007).

Table 1: Socio-Economics Characteristics of the Respondents

\begin{tabular}{llcc}
\hline S/N & Socio-Economic Characteristics & Frequency & Percentage \\
\hline & Sex & & \\
1. & Female & 98 & 62.8 \\
2. & Male & 58 & 37.2 \\
& Total & 156 & 100.0 \\
& Marital Status & & \\
\hline
\end{tabular}

